\title{
Jewels, Gems, and Magic Stones: The Uses of Stones in Natural Magic in the Middle Ages
}

\author{
Sonya Pihura
}

During the Middle Ages, belief in the supernatural was an inherent part of life. Christianity mixed with local traditions to create new religious customs, and was then institutionalized. ${ }^{1}$ Unsurprisingly, belief in other supernatural phenomenon such as magical practices was common as well. There were essentially two main branches of Medieval magic: demonic magic, in which the Devil and his minions were the source of power, and natural magic, which gained its power from God. ${ }^{2}$ Natural magic was concerned with stars, stones, herbs, and animals, and how their magical properties could be used to improve the lives of human beings. ${ }^{3}$

While such practices had been frowned upon in the earlier days of Christianity by theologians such as Saint Augustine of Hippo, they became more acceptable in the later Middle Ages. ${ }^{4}$ For example, in the thirteenth century Bishop Albertus Magnus wrote about the three Magi following a star to Bethlehem, and argued that this was a form of natural magic. ${ }^{5}$ An even earlier example is that of Bishop Marbod of Rennes, who wrote the Liber Lapidum, a lapidary, in the late eleventh century. ${ }^{6}$ Lapidaries were books that described the appearance and properties, both mundane and magical, of various rocks and minerals. ${ }^{7}$ Stones, jewels, and gems were of particular interest, since they were believed to be much more powerful than

\footnotetext{
${ }^{1}$ Miri Rubin, Medieval Christianity in Practice (Princeton: Princeton University Press, 2009), 1.

${ }^{2}$ Anne Lawrence-Mathers and Carolina Escobar-Vargas, Magic and Medieval Society (New York: Routledge, 2014), 52.

${ }^{3}$ Sophie Page, Magic in Medieval Manuscripts (Toronto: University of Toronto Press, 2004), 18.

${ }^{4}$ Ibid.

${ }^{5}$ Ibid.

${ }^{6}$ Lawrence-Mathers and Escobar-Vargas, Magic and Medieval Society, 54.

${ }^{7}$ Ibid.
} 
other substances such as herbs. ${ }^{8}$ Stones could be used simply as they were, or their power could be enhanced by engraving certain words and symbols onto them under the correct astrological conditions. ${ }^{9}$ These magical stones could be used in a variety of ways under different circumstances. In the Middle Ages magical stones were used medicinally, to bring good fortune, as protection from demons, and as a means to gain magical powers.

Since healers in Medieval times did not have the benefit of knowledge of accurate human physiology, let alone virology or germ theory, they often had to rely on superstitions, such as the magical powers of gemstones, to cure their patients. The stones could be worn on the body as jewelry or could be consumed as part of the remedy. In some cases, the stones used possessed supposedly magical properties, which allowed them to cure disease. For example opals were used to cure all manner of eye afflictions, ${ }^{10}$ while toadstone could allegedly cure kidney disease. ${ }^{11}$ Diamonds were considered especially powerful in this respect as they were said to have the power to cure insanity and counteract poisons, as well as protect one from the plague. ${ }^{12}$ In other instances, the illness in question was matched to a stone based on the principle of similia similibus curantur: like cures like. ${ }^{13}$ This meant that red stones, such as ruby or garnet, could be used to cure disorders of the blood and circulatory system, ${ }^{14}$ while yellow stones such as amber could be used to alleviate jaundice and other liver diseases. ${ }^{15}$ However some healers also believed in the idea that illnesses were just imbalances in the body and could be treated not with stones that shared traits with the afflicted organ or tissue but rather stones

\footnotetext{
${ }^{8}$ Richard Kieckhefer, Magic in the Middle Ages (Cambridge: Cambridge University Press, 2000), 103.

9 Don C. Skemer, Binding Words: Textual Amulets in the Middle Ages (University Park: Pennsylvania State University Press, 2006), 7-9.

${ }^{10}$ Sir E. A. Wallis Budge, Amulets and Talismans (New York: University Books, 1961), 320-321.

${ }^{11}$ Marian Campbell, Medieval Jewellery: In Europe 1100-1500 (London: Victoria and Albert, 2009), 75.

${ }^{12}$ Lawrence-Mathers and Escobar-Vargas, Magic and Medieval Society, 54.

${ }^{13}$ Monica Maria Stapelberg, Strange but True: A Historical Background to Popular Beliefs and Traditions (London: Crux Publishing, 2014).

${ }^{14}$ Budge, Amulets and Talismans, 322.

${ }^{15}$ Ibid., 308.
} 
that held opposite characteristics. Sapphire for instance, was used to treat excessive body heat and perspiration since its cold nature was thought to cool the body. ${ }^{16}$ In some circumstances the power of stones was used to enhance the magical properties of other substances, thereby making them more useful for medicinal purposes. Fennel on its own was thought to protect one's vision but if the fennel seeds were placed beneath a crystal then the seeds' potency doubled. ${ }^{17}$ While these remedies would have almost certainly been ineffective and would have at best created a placebo effect they were at least attempts to understand how the human body functioned and how to cure its many diseases. The use of magical stones to heal the sick in the Middle Ages demonstrates the belief in magic and tentative steps towards modern medicine.

Gems and jewels were not only used as medicine but as a means of gaining good fortune. The use of such stones particularly as talismans could help ensure good outcomes in one's endeavours. For instance rubies granted invulnerability to wounds, ${ }^{18}$ while diamonds were said to make one indomitable. ${ }^{19}$ These would certainly be useful when heading into battle or embarking on a dangerous journey. Likewise chelonite would ensure one was never cheated and diamonds could be used to overcome challenges and strife. ${ }^{20}$

While more mundane uses than invulnerability these stones would still have been very useful to the average person. Indeed, aristocracy and commoners alike owned and used supposedly magical gemstones, though the aristocracy of course could afford more of them. ${ }^{21}$ One common concern for both the rich and the poor was their salvation, which could also be aided by the powers of jewels. Sapphire was believed to be able to dispel envy a mortal sin and

\footnotetext{
${ }^{16}$ Kieckhefer, Magic in the Middle Ages, 103.

17 Ibid., 27.

18 Budge, Amulets and Talismans, 322.

19 Lawrence-Mathers and Escobar-Vargas, Magic and Medieval Society, 54-55.

${ }^{20}$ Ibid.

${ }^{21}$ Kieckhefer, Magic in the Middle Ages, 102.
} 
induce calm in the one who wore it. ${ }^{22}$ Moreover sapphires were thought to have the power to make one's prayers more favourable to God, which would bring good fortune indeed. ${ }^{23}$ Once again while these methods were very unlikely to have actually worked they do give insight into the Medieval world. The magical qualities ascribed to these stones show that they were concerned about mundane matters such as being cheated, but were also worried about death and the afterlife.

Protection from demons was another use for magical stones. In the Middle Ages, demonic forces were seen as a very real threat. People believed that the devil's minions lived in the air, in the water, and on land. ${ }^{24}$ Their purpose was to attack humans and tempt them to do evil, and thus lose their eternal salvation. ${ }^{25}$ Demons could create false images in the mind, cause disease and accidents, and even possess human beings. ${ }^{26}$ Naturally people wanted to find ways to defend themselves from these terrifying enemies. Diamonds and topaz were both used as a means to frighten demons and drive them off. ${ }^{27}$

Infants and young children were seen as especially vulnerable so they were often given talismans made of coral, which offered protection from evil forces, and also doubled as a teething ring. ${ }^{28}$ Clearly demonic forces were taken very seriously in the Middle Ages and they did whatever they could in order to protect themselves and their families.

In some cases, it was believed that gems and jewels could provide health and protection, but could also impart magical powers to the person who used them. For example, heliotrope could be used to give someone the gift of prophecy, and a bit of chelonite placed under the

\footnotetext{
${ }^{22}$ Kieckhefer, Magic in the Middle Ages, 103.

${ }^{23}$ Ibid.

${ }^{24}$ Jeffery Burton Russell, Lucifer: The Devil in the Middle Ages (Ithaca: Cornell University Press, 1986$), 42$.

${ }^{25}$ Ibid.

26 Ibid.

${ }^{27}$ Lawrence-Mathers and Escobar-Vargas, Magic and Medieval Society, 54-55.

${ }^{28}$ Skemer, Binding Words, 71.
} 
tongue would allow one to foretell the future. ${ }^{29}$ When chelonite was mixed together with the herb of the same name, the one who wore that substance was said to be able to become invisible. ${ }^{30}$ And even these powers were nothing to the magic one could perform with crystal. Crystal could be used to call together the four winds and to reveal hidden secrets to the stone's owner. ${ }^{31}$ Even more extraordinarily crystal could be used to gather demons and the spirits of the dead provided that the correct symbols had been carved into it. ${ }^{32}$ The most powerful stone of all, the diadocos could be used to summon the dead and if someone was buried with it they could not be called back to the world of the living. ${ }^{33}$ These ideas show that in the Middle Ages, magic was not only considered real, but as something that ordinary human beings could harness with the correct knowledge.

Stones and gems have been valued through history not only for their beauty but for the magical powers that are attributed to them. While the powers that people in the Middle Ages believed in were not true they do give insight into Medieval society. Stones were used as an attempt to cure sickness in an age where disease ran rampant and there was little knowledge of how to heal the body. Gems were thought to bring good luck to the ones who wore them, for both physical and spiritual matters. Moreover, certain jewels were thought to provide protection from demons, which were seen as both very real and dangerous. Finally, many people truly believed that humans could gain magical powers through the proper application of different stones. While this seems far removed from modern society many of the ideas remain constant. In the modern age experimental medicine is still used to treat patients, many people still believe in good luck charms. Further, although it may not be magic, through the

\footnotetext{
${ }^{29}$ Lawrence-Mathers and Escobar-Vargas, Magic and Medieval Society, 54-55.

${ }^{30}$ Ibid.

${ }^{31}$ Ibid, 27.

${ }^{32}$ Ibid.

${ }^{33}$ Ibid, 55 .
} 
application of new disciplines such as biotechnology and nanotechnology, scientists are rearranging the biotic and abiotic factors of the world in ways that in the Middle Ages would have been seen as nothing short of miraculous. While magic may not be a widespread belief in modern society the desire to cure the sick, to gain good fortune, and to bend the natural world to human desires still remain. 


\section{Bibliography}

Budge, Sir E. A. Wallis. Amulets and Talismans. New York: University Books, 1961.

Campbell, Marian. Medieval Jewellery: In Europe 1100-1500. London: Victoria and Albert, 2009.

Kieckhefer, Richard. Magic in the Middle Ages. Cambridge: University Press, 2000.

Lawrence-Mathers, Anne, and Carolina Escobar-Vargas. Magic and Medieval Society. New York: Routledge, 2014.

Page, Sophie. Magic in Medieval Manuscripts. Toronto: University of Toronto Press, 2004.

Rubin, Miri. Medieval Christianity in Practice. Princeton: Princeton University Press, 2009.

Russell, Jeffery Burton. Lucifer: The Devil in the Middle Ages. Ithaca: Cornel University Press, 1986.

Skemer, Don C. Binding Words: Textual Amulets in the Middle Ages. University Park: Pennsylvania State University Press, 2006.

Stapelberg, Monica Maria. Strange but True: A Historical Background to Popular Beliefs and Traditions. London: Crux, 2014. 